\title{
STIGMATISASI MAHASISWA TENTANG MARAKNYA MAHASISWA BERCADAR DI KAMPUS \\ (Studi Kasus Pada Mahasiswa Fakultas Ilmu Sosial dan Ilmu Politik Universitas Teuku Umar Meulaboh Kabupaten Aceh Barat)
}

\author{
Reni Juliani \\ Program Studi Ilmu Komunikasi, Universitas Teuku Umar \\ email: renijuliani@utu.ac.id
}

\begin{abstract}
Research on Student Stigma About the rise of students veiling on campus (case study at the Faculty of Social Sciences and Political Science at Teuku Umar University in West Aceh District).The purpose of this study is to familiarize students with stigmatization about the rise of students hiding at Teuku Umar Meulaboh University in the West Aceh district.The nature of this research is descriptive qualitative research, where this research aims to give a true picture, and statement on stigmatization of students Faculty of Social Sciences and Political Science at the University of Teuku Umar on rampant students who veiled on their campus.Data collection in this research is done through observation, interview and documentation. The results show that the stigma of the Faculty of Social Sciences and Political Science at the University of Teuku Umar against the veiled students is very positive that the veil has nothing to do with radicalism and terrorism and they accept the presence of students veiling their campus to have.This is because the location of Teuku Umar University in Aceh, which is the area of Islamic sharia and the majority of people accept Islam.Another reason is that there is no specific regulation at Teuku Umar University on how students should apply. The students have to dress politely and neatly.Mutual respect and respect are also the main factors in the non-discrimination of university students.But some students who have veiled at the University of Teuku Umar follow the latest trends.
\end{abstract}

Keywords: Stigma, Students, Veil

\section{PENDAHULUAN}

Cadar merupakan salah satu identitas keagamaan dalam agama Islam yang sering dikaitkan dengan budaya Arab. Wanita bercadar pada mayoritas wanita tidak bercadar akan terlihat berbeda karena cara berbusana mereka yang berlainan dan dipandang berbeda dengan wanita di sekitar mereka. Wanita bercadar sering menggunakan pakaian yang berwarna gelap, menggunakan penutup muka, berjilbab besar dan menggunakan jubah. Wanita bercadar biasanya yang terlihat hanyalah matanya saja karena wajahnya sudah ditutupi dengan cadar sehingga ketika bergaul mereka hanya dikenali dengan mata dan suaranya saja. 
Di Indonesia, tidak jarang akan kita jumpai wanita-wanita bercadar. Hal ini dikarenakan Indonesia merupakan negara yang penduduknya mayoritas muslim. Muslim di Indonesia banyak menganut faham-faham tertentu sehingga walaupun sesama muslim, mereka akan berbeda apabila menganut paham yang berbeda,baik dalam berbusana maupun cara bergaul mereka di dalam kehidupan sosial. Sebagai contoh fahamsalafi,kebanyakan wanita-wanita yang menganut faham ini biasanya bercadar.

Gerakan salafi mulai masuk ke Indonesia pada pertengahan 1980-an. Pengikut gerakan salafi ini memiliki ciri khas dalam penampilannya, yaitu untuk laki-laki biasanya memiliki jenggot panjang, berpakaian gamis, menggunakan sorban pada kepalanya, dan celana di atas mata kaki. Untuk perempuan biasanya menggunakan gamis warna hitam, kerudung yang lebar dan cadar (penutup muka). Gerakan salafi memperkenalkan ajaran Islam yang sangat tekstual dengan mengacu kepada keteladanan salafus shalih (muslim generasi awal). Para penganut gerakan ini secara ketat meniru segala hal yang dilakukan oleh salafus shalih sejak dari tata cara beribadah hingga berpakaian. Berbeda dengan kedua gerakan sebelumnya, Ikhwanul Muslimin dan Hizbut Takhrir, gerakan salafi ini berusaha memisahkan diri dari aktivitas politik karena mereka menganggapnya sebagai bid'ah. Biasanya mereka cenderung eksklusif atau memisahkan diri dari masyarakat dan membuat komunitas sendiri (Mustofa, 2012:72).

Perkembangan gerakan salafi di Indonesia menjadi salah satu faktor meningkatnya pengguna cadar di kalangan wanita. Dikarenakan Indonesia merupakan salah satu negara dengan muslim terbanyak, gerakan salafi ini mudah masuk dan hidup berdampingan dengan masyarakat yang bukan salafi. Keberadaan cadar bagi masyarakat Indonesia bukan lagi sesuatu yang asing. Masyarakat Indonesia hidup berdampingan dengan wanita-wanita bercadar di lingkungan sosial mereka. Walaupun cadar bukanlah hal baru bagi masyarakat Indonesia, tidak sedikit dari mereka yang masih memberikan jarak pada hubungan mereka dengan wanita-wanita bercadar. Masyarakat tersebut beranggapan bahwa cadar merupakan cara beragama yang belebihan dan cenderung dianggap fanatisme. Bahkan ada sebagian dari mereka yang menolak keberadaan wanita bercadar dan melakukan berbagai diskriminasi kepada mereka karena dikaitkan dengan kelompok Islam radikal. Dan yang lebih parahnya lagi, wanita bercadar sering dianggap teroris dan penganut ajaran sesat.

Adanya anggapan cadar, radikalisme dan terorisme mempunyai kaitan satu sama lain. Hal ini merupakan stigma yang dibangun masyarakat dalam mengartikan keberadaan cadar di dalam kehidupan mereka. Selain itu yang memperburuk hubungan masyarakat dengan wanita bercadar adalah sikap mereka yang agak tertutup.Ketertutupan komunitas cadar ini menjadi salah satu faktor menghambat proses sosialisasi mereka dengan masyarakat. Masyarakat beranggapan cadar belum bisa menyatu secara sepenuhnya dengan Muslim di Indonesia. Sehingga hal ini membuat wanita bercadar terbatas dalam berkomunikasi. Penggunaan cadar tidak 
wajib di Indonesia. Oleh sebab itu ada sebagian pihak yang menegaskan penggunaan cadar itu harus disesuaikan dengan lingkungan.

Baru-baru ini diskriminasi terhadap wanita bercadar semakin terlihat. Di kampus dan di berbagai instansi pendidikan, ada larangan wanita untuk bercadar. Seperti kasus pada Universitas Islam Negeri (UIN) Sunan Kalijaga yang mengeluarkan peraturan larang mahasiswanya menggunakan cadar karena dianggap memiliki paham radikal. Seperti yang dilansirkan oleh voaindonesia.com pada tanggal 8 Maret 2018, Rektor UIN Sunan Kalijaga mengatakan bahwa radikalisasi yang dicontohkan dengan pemakaian burka merusak proses belajar. Mahasiswi yang mengenakan burka dan kelompok-kelompok radikal, mereka mengganggu proses mengajar. UIN Sunan Kalijaga mengedepankan Islam yang moderat sehingga larangan ini merupakan tindakan pencegahan untuk menyelamatkan para mahasiswa dan mahasiswi.

Rektor Universitas Ahmad Dahlan (UAD) Yogyakarta memberikan komentarnya terkait masalah mahasiswa bercadar di kampus. Beliau beranggapan bahwa cara berpakaian harus sesuai dengan tuntutan Rasulullah. Berpakaian cukup dengan menutup aurat. Oleh sebab itu apabila sampai menutup muka, muka merupakan bagian yang tidak perlu harus ditutup-tutupi. Jadi, menutup aurat memakai cadar dinilai tergolong berlebihan dan tidak sesuai dengan ajaran ke-Muhammadiyah-an (Nugroho, 2018).

Fenomena yang terjadi belakangan ini adalah mulai meningkatnya mahasiswa yang menggunakan cadar di kampus-kampus tempat mereka menempa pendidikan. Hal ini juga terjadi di Universitas Teuku Umar (UTU) Meulaboh Kabupaten Aceh Barat yang merupakan satu-satunya universitas negeri di Aceh Barat. Oleh sebab itu, fenomena tersebut yang melatarbelakangi penelitian ini harus diteliti. Penelitian ini berkaitan mengenai strigmatisasi mahasiswa tentang maraknya mahasiswa bercadar di Universitas Teuku Umar. Informan penelitian ini adalah mahasiswa FISIP UTU dikarenakan mereka adalah mahasiswa yang mempelajari ilmu-ilmu sosial masyarakat. Tujuan penelitian ini adalah untuk mengetahui bagaimana stigmatisasi mahasiswa FISIP UTU mengenai maraknya mahasiswa yang bercadar di kampus mereka.

\section{TINJAUAN PUSTAKA}

Durkheim (Dermawan dan Oli'i, 2015:12) berpendapat bahwa salah satu hukuman sosial yaitu sigmatisasi yang merupakan tanda-tanda konkret dalam hal mana masyarakat mengekspresikan ketidaksetujuan, celaan dan kekuatan tatanan moral. Di dalam kehidupan masyarakat kita banyak menemukan berbagai stigmatisasi. Goffman (Fatmawati, 2015:3) menyebutkan 3 tipe stigma yang diberikan terhadap seseorang, yaitu:

1) Stigma yang berhubungan dengan kecacatan pada tubuh seseorang (cacat fisik)

2) Stigma yang berhubungan dengan kerusakan-kerusakan karakter individu, missal homosexuality. 
3) Stigma yang berhubungan dengan ras, bangsa dan agama.

Berdasarkan penjelasan Goffman di atas, stigma mengenai cadar termasuk kepada stigma ketiga yaitu stigma yang berhubungan dengan agama. Faktor agama ini menjadi menarik karena di dalam kasus cadar, yang menentang keberadaannya bahkan bukan dari masyarakat agama yang berbeda, namun masyarakat sesama muslim. Seperti contoh kasus pelarangan bagi mahasiswanya untuk menggunakan cadar di Universitas Islam Negeri (UIN) Sunan Kalijaga. UIN Sunan Kalijaga merupakan universitas Islam. Sedikit aneh apabila universitas tersebut melarang salah satu aktribut keagamaan (cadar) dalam salah satu faham di agama Islam dilarang untuk digunakan. Hal ini sama saja mereka menolak keberadaan salah satu faham. Padahal sebagai manusia kita harus menghormati manusia lainnya. Bahkan di Indonesia kita berhak beragama sesuai dengan keyakinan kita. Oleh sebab itu larangan tersebut terkesan tidak mendasar apabila cadar diidentikkan dengan faham garis keras.

Sikap masyarakat yang terbagi menjadi pro dan kontra dalam menyikapi keberadaan wanita bercadar pada dasarnya juga tidak dapat dipisahkan dari adanya pendapat yang bertentangan dari para ulama mengenai apakah penggunaan cadar bagi wanita Muslim adalah suatu keharusan atau tidak. Ada kelompok ulama yang berpendapat bahwa hukum pemakaian cadar adalah wajib (Mahzab Safi'i) dan ada yang mengatakan hukumnya sunnah atau afdhol dan merupakan keutamaan bila melakukannya (Mahzab Maliki dan Hanafi). Mereka yang tidak mewajibkan beralasan, bahwa aurat seorang wanita itu adalah seluruh tubuh terkecuali wajah dan telapak tangan. Kedua pendapat tersebut berangkat dari penfsiran yang berbeda terhadap satu ayat Al-Qur'an, yaitu surat Annur ayat 31 yang artinya :

"Katakanlah kepada wanita yang beriman, hendaklah mereka menahan pandangannya dan memelihara kemaluannya janganlah mereka menampakkan perhiasan mereka kecuali yang biasa tampak dari mereka dan hendaklah mereka menutupkan kain kerudung ke dada mereka dan janganlah menampakan perhiasan mereka, kecuali kepada suami mereka, atau ayah mereka, atau ayah suami mereka, atau putraputri mereka, atau saudara lakilaki mereka, atau putra-putri saudara laki-laki mereka, atau perempuanperempuan muslim atau hamba-hamba sahaya yang mereka miliki, atau pelayan-pelayan laki-laki yang tidak punya hasrat (terhadap perempuan) atau anak-anak yang belum mengerti tentang aurat perempuan. Dan janganlah mereka memukulkan kaki mereka agar diketahui perhiasan yang mereka sembunyikan. Dan bertaubalah kalian kepada Allah, wahai orang-orang yang beriman supaya kalian beruntung" (Novi, 2016:3-4).

Para muslimah bercadar menjadikan jilbabnya sebagai pelindung, baik itu pelindung fisik maupun pelindung kehormatan mereka. Pada dasarnya jilbab yang disertai cadar menurut mereka berfungsi sebagai pelindung ekstra artinya jilbab dapat melindungi muslimah dari gangguan negatif ataupun gangguan-gangguan dari halhal yang tidak diinginkan (Rusmiyanti, 2017:4). Apabila perlindungan itu dicabut dan 
ditiadakan, hak-hak mereka juga dilanggarkan. Setiap manusia berhak berekspresi. Negara kita merupakan negara yang demokratis dimana setiap masyarakatnya bebas berekspresi. Apalagi menyangkut keagamaan. Ajaran agama yang tidak sesat sifatnya diperbolehkan, namun terkadang dikarenakan isu-isu negatif di media massa mempengaruhi cara masyarakat memandang suatu kegiatan agama yang sebenarnya lumrah menjadi pandangan yang negatif.

Keberadaan perempuan bercadar masih belum dapat diterima secara penuh oleh masyarakat, terdapat persepsi negatif dari masyarakat penggunaan cadar yang dilakukan para perempuan tersebut menganggu proses hubungan antarpribadi di dalam masyarakat. masayarakat juga beranggapan bahwa perempuan yang memakai cadar itu hanya kedok belaka mereka beranggapan bahwa perempuan yang memakai cadar adalah teroris atau penganut aliran sesaat dan ada pula sebagian masyarakat yang beranggapan bahwa perempuan bercadar tidak mau bersosialisasi dengan masyarakat lainnya, bahkan ada masyarakat yang menggagap cadar hanya alat untuk menutup-nutupi kejelekanya. Selama sebab-sebab perbedaan pendapat itu masih ada, maka ikhtilaf (perbedaan pendapat) itu akan senantiasa ada diantara manusia, meskipun mereka sama-sama muslim, patuh pada agamanya, dan ikhlas. Bahkan kadang-kadang komitmen dan keikhlasan terhadap agama menyebabkan perbedaan pendapat itu semakin tajam. Masing-masing pihak ingin mengunggulkan dan memberlakukan pendapat yang diyakininya benar sebagai ajaran agama yang akan diperhitungkan dengan mendapatkan pahala (bagi yang melaksanakannya) atau mendapatkan hukuman (bagi yang melanggarnya) (Tanra, 2015:117).

Dalam tahun-tahun terakhir, telah ada kumpulan peraturan yang substansial yang didorong oleh ketakutan yang didasarkan pada gambaran-gambaran stereotip gerakan keagamaan baru. Kecenderungan ini telah berjalan secara paralel dalam banyak cara dengan peraturan yang didorong oleh ketakutan akan "ekstremis agama" dari sejumlah tradisi. Sementara peristiwa yang terjadi di tahun-tahun terakhir tidak diragukan lagi merupakan persoalan yang sungguh-sungguh terjadi, relasi hukum sering berlebihan, memaksakan pembatasan-pembatasan terhadap kelompokkelompok yang sah yang tidak konsisten dengan norma-norma kebebasan beragama (Lindholm, Jr dan Thazib-Lie, 2010:42).

Adanya ketakutan menganai "ekstremis agama" yang menyebabkan cadar dianggap terkait dengan radikalisme dan terorisme. Sehingga terjadi ketidakadilan terhadap wanita bercadar yang ingin diakui keberadaannya di dalam masyarakat. Apabila masyarakat melakukan pengucilan terhadap wanita bercadar, maka masyarakat telah melakukan dikriminasi terhadap wanita bercadar itu. Diskriminasi tidak hanya terjadi secara fisik semata, seperti kekerasan, pembantaian dan perlakuanperlakuan kasar lainnya. Diskriminasi dengan cara mencemooh, mengucilkan dan memberikan pandangan negatif terhadap kelompok lain disebut juga sebagai diskriminasi.

Diskriminatif adalah sikap yang merupakan usaha untuk membedakan secara 
sengaja terhadap golongan-golongan yang berkaitan dengan kepentingan tertentu; dalam diskriminatif, golongan tertentu diperlakukan berbeda dengan golongangolongan lain; pembedaan itu dapat didasarkan pada suku bangsa, agama, mayoritas, atau bahkan minoritas dalam masyarakat, diskriminatif adalah bersifat aktif atau aspek yang dapat terlihat dari prasangka yang bersifat negative terhadap seorang individu atau suatu kelompok. "Diskriminatif mencakup perilaku apa saja, yang berdasarkan perbedaan yang dibuat berdasarkan alamiah atau pengkategorian masyarakat, yang tidak ada hubungannya dengan kemampuan individu (Fatmawati, 2015:6). Diskriminasi sosial yang dilatarbelakangi dari pelabelan yang berkonotasi negatif, cenderung menjadi pribadi korbannya minder dan sulit dalam pergaulan di tengah-tengah masyarakat. Meskipun belum tentu benar pelabelan itu, namun dampak yang mengenainya sangat menekan psikis korban itu sendiri, itulah yang sering disebut oleh akademisi sebagai stigmatisasi. (Mustofa, 2016:5).

Kondisi diskriminasi atau non diskriminasi di suatu wilayah bisa dilihat sebagai proses daling mempengaruhi antara peran struktur sosial dan peran aktor. Individu hidup dalam suatu struktur tertentu yang bisa membentuk individu. Tetapi pada saat yang bersamaan, individu juga bisa mengubah struktur tersebut. Kondisi diskriminasi lahir dari struktur tertentu seperti tidak adanya jaminan hukum, negara yang otoriter, stereotip yang buruk terhadap kelompok lain, tradisi serta warisan masa lalu, dan sebagainya. Struktur ini bisa membentuk individu yang hidup di suatu wilayah yang menjadi pribadi yang diskriminatif. Tetapi proses ini tidak kaku. Manusia bukanlah mesin yang terus menerus didikte oleh struktur. Meski berada dalam struktur yang diskriminatif, individu pada dasarnya juga secara aktif bisa mengubah, dan menyesuaikan diri. Sejarah memperlihatkan banyak wilayah yang semula diskriminatif bisa keluar dari kondisi diskriminatif ketika aktor secara aktif mengubah kondisi yang diskriminatif tersebut. Melalui proses yang panjuang, aktor tersebut tidak larut dan dibentuk oleh kondisi diskriminatif, tetapi tampil dengan mengubah struktur diskriminatif (Ali, 2014:7).

Diskriminasi terhadap wanita bercadar dikarenakan cadar tersebut dicap sebagai pakaian kelompok agama radikal dan teroris, maka masyarakat telah menciptakan julukan kepada cadar itu. Dalam ilmu sosiologi, julukan tersebut dinamakan labelling. Kita sering mendengar kata label dimana merujuk kepada kata merek. Label dalam kasus in dimana masyarakat memerekkan kelompok tertentu atas dasar alasa tertentu. Label inilah yang membuat mereka dibedakan di dalam kehidupannya bermasyarakat. Sehingga akibat dari label ini, kelompok tersebut akan dikucilkan dalam pergaulannya.

Teori Labelling dikemukakan oleh Edwin M. Lemert. Labellingadalah proses melabel seseorang. Label, menurut A Handbook for The Study of Mental Health, adalah sebuah definisi yang ketika diberikan kepada seseorang akan menjadi identitas diri orang tersebut, dan menjelaskan orang dengan tipe bagaimanakah dia. Dengan memberikan label pada diri seseorang, kita cenderung melihat dia secara keseluruhan kepribadiannya, dan buka pada perilakunya satu per satu. Teori penjulukan, secara 
sederhana, hanya menyatakan dua hal. Pertama, orang berperilaku normal atau tidak normal, menimpang atau tidak menyimpang, tergantung pada bagaimana orang lain menilainya. Penilaian itu ditentukan oleh kategorisasi yang sudah melekat pada pemikiran orang lain. Segala sesuatu yang dianggap tidak termasuk ke dalam kategori-kategori yang sudah dianggap baku oleh masyarakat (dinamakan residual), otomatis akan dikatakan menyimpang seorang devians). Kedua, penilaian itu berubah dari waktu ke waktu, sehingga orang yang katakanlah hari ini dinyatakan sakit bisa dinyatakan sehat (dengan gejala yang sama) beberapa tahun kemudian, atau sebaliknya (Ahmadi dan H, 2005:299).

Pada tataran teoritis, labelling mengandung ide tentang arti diri seorang individu dalam kancah "panggung sandiwara" atau dalam kehidupan sosial. Labelling pada akhirnya sering diartikan sebagai cap sosial atas seorang individu sehingga terjadi semacam kontrol sosial atas diri seorang individu. Teori labelling ini menjadi sangat penting sebagai titik temu antara interaksi simbolik dan bebara tren atau cara pandangan dalam pembelajaran mengenai budaya (Sutrisno dan Putranto, 2005:81).Labelling ini juga terkait dengan simbol-simbol yang mereka gunakan sehingga mereka dianggap berbeda. Cadar merupakan simbol yang membedakan kelompok bercadar dengan masyarakat lainnya. Di dalam berinteraksi, mereka juga berbeda dikarenakan sifat tertutup kelompok bercadar sehingga interaksi mereka dengan masyarakat juga renggang. Masyarakat yang berinteraksi dengan kelompok bercadar sering menjaga jarak karena simbol yang mereka gunakan yaitu cadar sehingga memberikan batasan mereka dalam berinteraksi.

Blumer mengembangkan lebih lanjut gagasan Mead dengan mengatakan bahwa ada lima konsep dasar dalam interaksi simbolik, yaitu Pertama, konsep diri (self), memandang manusia bukan semata-mata organisme yang bergerak di bawah pengaruh stimulus, baik dari luar maupun dari dalam, melainkan "organisme yang sadar akan dirinya" (an organism having a self). dia mampu memandang diri sebagai objek pikirannya dan bergaul atau berinteraksi dengan diri sendiri. Kedua, konsep perbuatan (action), karena perbuatan manusia dibentuk dalam dan melalui proses interaksi dengan diri sendiri, maka perbuatan itu berlainan sama sekali dengan gerak makhluk selain manusia. Manusia menghadapi berbagai persoalan kehidupannya dengan beranggapan bahwa dia tidak dikendalikan oleh situasi, melainkan merasa diri di atasnya. Manusia kemudian merancang perbuatannya. Perbuatan manusia itu tidak semata-mata sebagai reaksi biologis, melainkan hasil konstruksinya. Ketiga, konsep objek (object), memandang manusia hidup di tengah-tengah objek. Objek itu dapat bersifat fisik seperti kursi, atau khayalan,kebendaan atau abstrak seperti konsep kebebasan, atau agak kabur seperti ajaran filsafat. Inti dari objek itu tidak ditentukan oleh ciri-ciri instrinsiknya, melainkan oleh minat orang dan arti yang dikenakan kepada objek-objek itu (Ahmadi 2005:303).

Keempat, konsep interaksi sosial (social interaction), interaksi berarti bahwa setiap peserta masing-masing memindahkan diri mereka secara mental ke dalam posisi orang 
lain. Dengan berbuat demikian, manusia mencoba memahami maksud aksi yang dilakukan oleh orang lain, sehingga interaksi dan komunikasi dimungkinkan terjadi. Interaksi itu tidak hanya berlangsung melalui gerakgerik saja, melainkan terutama melalui simbolsimbol yang perlu dipahami dan dimengerti maknanya. Dalam interaksi simbolik, orang mengartikan dan menafsirkan gerak-gerik orang lain dan bertindak sesuai dengan makna itu. Kelima, konsep tindakan bersama (joint action), artinya aksi kolektif yang lahir dari perbuatan masing-masing peserta kemudian dicocokan dan disesuaikan satu sama lain. Inti dari konsep ini adalah penyerasian dan peleburan banyaknya arti, tujuan, pikiran dan sikap. Oleh karena itu, interaksi sosial memerlukan banyak waktu untuk mencapai keserasian dan peleburan. Eratnya kaitan antara aktivitas kehidupan manusia dengan simbol-simbol karena memang kehidupan manusiasalah satunya berada dalam lingkungan simbolik (Ahmadi 2008:304).

\section{METODE PENELITIAN}

Jenis penelitian yang dilakukan adalahjenis penelitian kualitatif.Jika dilihat dari jenis dan obyek yang diteliti, maka penelitian ini dikategorikan sebagai penelitian studi kasus dengan maksud memberikan gambaran tentang stigmatisasi mahasiswa FISIP UTU terhadap maraknya mahasiswa bercadar di Universitas Teuku Umar. Informan ditentukan secara purposive sampling. Informan dalam penelitian ini adalah mahasiswa FISIP UTU yang berjumlah 10 orang. 5 orang mahasiswa laki-laki dan 5 orang lainnya adalah mahasiswa perempuan.Teknik pengumpulan data dalam penelitian ini dengan cara observasi, wawancara, dan dokumentasi, kemudian data yang didapatkan ldianalisis melalui tahap reduksi data, penyajian data, lalu kemudian penarikan kesimpulan.

\section{HASIL DAN PEMBAHASAN}

Dari wawancara yang peneliti lakukan terhadap 10 orang Mahasiswa FISIP UTU, maka dapat kita ketahui bagaimana pandangan mereka terhadap cadar. Seluruh informan menganggap cadar merupakan bentuk pendekatan diri kepada Tuhan. Cadar merupakan salah satu cara yang dilakukan untuk meningkatkan marwah wanita dan sebagai pelindung wanita. Seperti yang dikatakan oleh informan 6 yaitu:

"Menurut saya cadar adalah sesuatu yang baik untuk wanita agar lebih menjaga dirinya, saya sangat mendukung dan senang dengan cadar. apalagi Indonesia negara mayoritas muslim terlebih Aceh yg dijuluki seuramoe mekkah ini. Dalam 4 mazhab disebutkan hukum cadar yang berbeda, ada mazhab yg mewajibkan dan ada yang sunnah. Kita memakai mazhab imam syafi'i yang dalam sebuah kitab dijelaskan bahwa hukum cadar adalah sunnah namun menjadi wajib jika wajahnya terlalu cantik sehingga dikhawatirkan akan menimbulkan fitnah." 
Penjelasan di atas sesuai dengan pendapat Informan 10 bahwa "Pandangan saya tentang cadar positif ya, karena cadar kan identitas muslimah ya meskipun tidak diwajibkan". Penggunaan cadar tidak wajib menurut mereka. Seperti yang diungkapkan oleh Informan 4 bahwa "Tidak ada yang salah tentang seseorang yang pakai cadar karena itu hak orang mau memakainya atau tidak memakai cadar itu kan sunnah sebagian orang jika bisa mengejar sunnah mengapa tidak"

Informan 7 juga menambahkan bahwa "Cadar salah satu cara untuk menutup aurat, walau dianjurkan wanita menutup aurat tidak diharuskan dan diwajibkan memakai cadar, cadar menjadi wajib menurut salah satu dari 4 mashab yang mungkin menjadi rujukan dan panutannya." Begitu juga dengan informan 8 , ia menyebutkan pandangannya tentang cadar bahwa "Pandangan saya tentang cadar, bagus. Tidak aneh. Karna cadar dalam agama Islam kan untuk meninggikan Marwah perempuan. Dalam Islam, cadar itu untuk menutupi perempuan dari fitnah."

Mahasiswa FISIP UTU tidak memandang buruk mengenai cadar. Keseluruh informan sepakat bahwa cadar adalah hal positif dari segi pendalaman agama. Seperti yang dikemukakan oleh informan 1 yaitu:

"Menurut mindset pola pikir saya sendiri atau pandangan saya, cadar itu hal yang wajar terjadi di kalangan masyarakat kita sendiri, karena apa cadar itu keharusan yang harus di gunakan untuk wanita bukan hal paksaan tetapi hal hati nurani nya sendiri, dimana orang memakai cadar itu adalah orang yang telah di sentuh hatinya terasa nyaman dgn banyak pertimbangan dalam hal konteks mendengarkan tausiyah maupun menuntut ilmu di ponpes. Dlm segi ini kembali lagi ke poin pertama dimana menurut hati nya sendiri, karna saya bisa memberikan contoh wanita yang memakai cadar yaitu berkas mantan pacar saya sendiri: menurut dia memakai cadar adalah hal yang terjadi di dalam dirinya untuk berhijrah bukan karna faktor yang lain"

Tingkah laku Mahasiswa UTU setelah bercadar menjadi berubah. Hal ini disepakati oleh kebanyakan informan yang diwawancarai. Informan 8 menjelaskan "Ya sangat berubah. Menjadi pendiam dan jarang ngumpul, suka mengasingkan diri dan memilih-milih teman. Bahkan jarang muncul di group dan tidak pernah lagi nongkrong diluar kampus bareng-bareng dan sangat susah diajak keluar."Informan 9 juga memberikan pendapatnya "mereka jadi lebih religius dan menjaga jarak untuk tidak dekat dengan teman laki laki di kelas yang awalnya dekat, nyanyi bareng sekarang sudah jarang bahkan tidak lagi, setelah selesai perkuliahan ia nya langsung pulang kalau tidak ikut kegiatan liqaq, LDK dan organisasi lainnya." Informan 10 lebih menilai perubahan dari segi berbicara "Berubah dari segi berbicara nya. Kalo yang lain kayanya sama aja." Informan 5 menambahkan "Secara sikap mungkin ia mulai agak tertutup."

Namun Informan 7 beranggapan bahwa perubahan mahasiswa bercadar tidak terlihat banyak. Mereka masih dianggap sama seperti sebelum mereka bercadar dan dianggap sikap mereka tidak seperti sikap orang bercadar yang seharusnya. 
"Sedikit berbeda dari sebelumnya. Yang saya lihat, bahkan saya amati, dia tidak berubah dalam tutur katanya, masih tetap seperti biasa. Mungkin sedikit berbeda di bagian seperti nimbrung pembicaraan orang lain dengan ceramah, namun bagi kami cara ceramahnya dalam konteks yang salah. Mereka lebih ke pakain saja, tapi tutur kata dan bahasanya sama saja. Masih suka ketawa gede gede, ada centil nya gitu. Mungkin karna mereka bercadar, mereka juga punya hak untuk mengekspresikan diri mereka, padahal itu tetap salah dalam ranah agama. Ya masih sama sih, mungkin agak sedikit diem."

Alasan Mahasiswa UTU menggunakan cadar beragam. Ada yang memilih bercadar karena memang memilih untuk hijrah dan memperbaiki diri mereka. Namun ada pula yang ikut-ikutan trend dan tidak mengetahui alasan yang jelas mengapa mereka bercadar. Seluruh informan setuju apabila sebagian Mahasiswa UTU yang menggunakan cadar dikarenakan ikut-ikutan teman mereka yang sudah lama bercadar, namun sebagian lainnya Mahasiswa UTU bercadar karena berikhtiar untuk mendalami agama dengan baik lagi. Seperti yang diungkapkan oleh informan 9,

"Karena mungkin mereka sudah memantapkan diri untuk benar-benar menutup aurat sesuai anjuran Allah, namun dalam pandangan saya terlalu mendadak dan terasa hanya mengikuti trend walau banyak akhwat muslimah yang sudah mulai camplain tentang cadar dan menutup aurat sesuai konteks syariah di Aceh. Ada satu masalah pada mahasiswi yang bercadar mereka mungkin akan membuka kembali cadarnya apa bila dianggap tidak kuat dan bisa istiqamah memakainya seperti kasus salah satu siswi yang sudah membuka cadarnya kembali tanpa ada tahu maksud dari peristiwa membuka cadarnya kembali."

Fenomena di atas juga ditegaskan oleh informan 7, yaitu:

"Pandangan saya, ini seperti trend. Bukan digunakan untuk membenahi diri. Karena, di UTU, saya lihat banyak yang mulai memakai cadar namun seperti terkesan hanya terobsesi saja. Ketika trend hilang cadar bisa jadi akan dilepas. Mereka seperti ada keinginan namun bersifat sementara yang katanya ingin hijrah. Dan yang saya lihat mayoritas di UTU yang memakai cadar bukan memakai cadar, tapi mengganti dengan memakai masker yang dianggap oleh mereka untuk mencoba dulu, untuk melatih dulu, atau untuk meyakinkan dengan betqh memakai masker setelah itu baru berlanjut memakai cadar. Intinya menurut saya, terkesan seperti mengganggap cadar adalah hal yang sepele, bisa sekehendak hati, bukan pasang buka pasang. Jadi, jujur saya yang melihat yang terjadi di UTU, seolah menyepelekan agama, dan saya yang melihat mereka seolah menutupi wajah dengan cadar lebih penting ketimbang ilmu agama yang masih minim bahkan masih banyak kita jumpai yang memakai cadar, tapi ilmu agama sangat kurang. Dan sebenarnya mereka tidak memikirkan hakikatnya, mereka juga tidak memikirkan ketika mereka buka pasang cadar dan menggantikannya dengan masker, pendapat non-muslim 
akan berbeda, mereka akan memandang Islam itu terkesan 'kok gitu'. Bahkan kami yang memandangnya jadi tidak suka dengan sikap buka pasang."

Infroman 1 juga beranggapan mengenai sebagian Mahasiswa UTU yang memilih bercadar dikarenakan bukan trend "Itu hal yang wajar juga bagi saya, bagus mereka banyak bercadar karna dia mulai tersentuh hatinya untuk berhijrah, karna mereka sudah tersentuh hatinya untuk berhijrah, bukan untuk memamerkan kepada orang lain yaitu dalam konteks ikut-ikutan orang karna memakai cadar, tetapi karna hati nya yang mulai tersentuh untuk berhijrah. Saya suka, tetapi dalam konteks yang benarbenar mengerti tentang hal agama yaitu dalamm mereka hijrah."

Informan 6 menyebutkan kejadian yang dialaminya yang membuatnya kecewe dengan wanita bercadar sehingga hilangnya ketertarikannya untuk bercadar. Ia mengungkapkan bahwa:

"Rencana sudah ada sejak lama, namun akhir-akhir ini melihat fenomena yang terjadi saya merasa tidak tertarik lagi bercadar. Dulu saya merasa jiwa saya tenang dan nyaman melihat orang-orang bercadar. Namun skrg seperti pikiran jorok terhadap orang-orang bercadar. Dipasar saya pernah melihat orang bercadar tapi betisnya keliatan ketika dia naik motor, bercadar tapi masih pacaran, bercadar tp baju dalamnya pendek, katanya karna jilbabnya udah besar jadi ga akan keliatan keluar dan lain-lain. Sehingga perspektif orang terhadap cadar itu tidak baik. Saya sendiri pernah memakai cadar di lingkungan pesantren saya di Indrapuri, karena disana wajib bercadar jika keluar asrama. Sebenarnya selama ini yang salah adalah orang-orang yang memakai cadar bukan cadarnya. Tetapi isu yang berkembang adalah seakan akan cadar yang selalu salah dan disalahkan. Smenurut saya sebenarnya ada hal lain yg lebih baik jika diutamakan daripada cadar. Seperti memahami hokum-hukum agama dulu. tauhid, aqidah, fiqh, tassawufnya. Jika memang mampu baru menjalankan sunnah cadar. Karna kita memakai hukum cadar itu sunnah. Jadi hal-hal wajib dulu yang baik kita pelajari."

Dari hasil wawancara di atas dapat kita tarik kesimpulan bahwa sebagian Mahasiswa UTU yang bercadar karena alasan trend sebenarnya belum memiliki kedalam agama. Mereka sebenarnya masih ragu dengan pilihan mereka bercadar. Belum ada kemantapan dalam hati mereka. Hal inilah yang membuat mereka membuka tutup cadar yang mereka gunakan. Sehingga mahasiswa lainnya beranggapan mereka tidak konsisten dengan keputusan mereka dan merasa melecehkan agama dengan keraguan yang mereka lakukan. Dari pernyataan di atas. Cadar dianggap hal postif. Orang-orang yang bercadar yang tidak bertanggung jawab dengan keputusannyalah yang menjadikan artian cadar terhadap masyarakat menjadi negatif. Namun keseluruhan informan sepakat bahwa di Universitas Teuku Umar (UTU) tidak pernah ada pengucilan dan diskriminasi terhadap orang-orang yang bercadar. Seperti yang diungkapkan oleh informan 7 bahwa "Tidak. Kampus saya tidak ada diskriminasi dan pengecualian terhadap yang bercadar. Tidak ada larangan 
atau perbedaan bagi yang bercadar. Biasa saja." Hal ini juga ditegaskan oleh informan 6 mengenai alasan mengapa di UTU tidak terjadi diskriminasi terhadap mahasiswa yang bercadar. Pandangannya sebagai berikut:

"Mungkin yang pertama karena Aceh adalah daerah yang kental Islam sehingga orang melihat cadar hal yang biasa. Kemudian di UTU tidak ada Ormas khusus agama yang mengurusi cadar atau hal lain, kebanyakan di UTU mahasiswanya lebih sensitif terhadap politik kampus. Dan itu juga hak seseorang untuk bercadar dan tidak. Di UTU pun tidak ada aturan khusus tentang busana. Hanya seperti aturan memakai pakaian yang sopan ke kampus."

Informan 8 juga beranggapan bahwa "Kalau dikampus UTU belum pernah hanya saja mungkin jumlah mahasiswi yang pakai cadar sedikit dan apabila ia keluar dari rombongan atau kelompok teman lamanya nampak seperti dikucilkan tapi sebenarnya tidak. Tapi kalau di universitas di Jawa Saya pernah dengar tentang diskriminasi mahasiswi yang bercadar malah tidak diperbolehkan." Ia menambahkan alasan mengapa mahasiswa di UTU terkesan pro terhadap cadar

“Karena mungkin mahasiswi di UTU mayoritas Islam dan berasal dari Aceh dengan pengalaman dan ilmu yang mungkin ada sebagian dari mereka berasal dari pasantren dan lagi karena Mahasiswi UTU sudah mulai aktif di organisasi agama misal LDK, HMI,dan liqaq pengajian jadi mereka sudah memaklumi dan paham akan mengapa sebagian mahasiswi memutuskan bercadar dengan keyakinan dan istiqamah masing-masing siswi, dan lagi sekarang lagi ada banyak kampanye menutup aurat dan cadar untuk menegakkan hukum syariat di Aceh."

Informan 1 juga menambahkan perihal tidak adanya diskriminasi mengenai mahasiswa yang memakai cadar di UTU, "Karna, yang pertama kita tau persis jika kita berdiri dan tinggal di bumi serambi Makkah di mana masyarakat luas menilai Aceh kuat/kental dgn syariah Islam. Yang kedua masyarakat kita sudah tahu betul tentang hukum-hukum Islam, karna itulah mereka tidak melakukan penolakan terhadap mahasiswi bercadar." Hal ini juga ditegaskan oleh Informan 6, yaitu:

“Karna UTU berdiri di Aceh, jadi mayoritas muslim. Dan itu menjadi kenapa tidak ada larangan bagi yang bercadar. Dan belum pernah dijumpai pada orang bercadar seperti teroris, atau bom dan sebagainya yang bersifat radikal pada mereka. Agama Islam menjadi salah satu kenapa di UTU tidak ada larangan dan diskriminasi terhadap yang bercadar, UTU letaknya di Aceh Barat. Aceh adalah serambi mekkah, jadi mayoritas muslim di UTU juga penentu yang sangat besar."

Pernyataan di atas sekaligus menolak stigma yang selama ini berkembang di masyarakat bahwa orang-orang yang bercadar terkaait dengan radikalisme dan terorisme. Pendapat Informan tersebut menegaskan kalau perilaku mahasiswa bercadar di UTU jauh dari sikap radikal dan keras. Hal ini merupakan salah satu 
alasan mengapa cadar tidak dilarang di UTU dan tidak ada tindakan yang menjurus kepada diskriminasi terhadap mahasiswa yang bercadar di UTU.

Walaupun di UTU tidak ada diskriminasi terhadap mahasiswa yang bercadar, para informan mengakui kalau ada sebagian teman mereka yang suka usil dan bercanda masalah cadar. Ada yang menggoda mahasiswa bercadar. Namun hanya sebatas itu. Kebanyakan Mahasiswa UTU menghargai keputusan mahasiswa yang memilih hijrah dan bercadar. Hal ini seperti yang diungkapkan oleh informan 2 "Mengejek sih tidak tapi hanya bercanda dengan mereka dan agak sedikit jail." Informan 3 dan 5 menjelaskan hal yang sama bahwa ada sebutan-sebutan seperti ninja yang ditujukan kepada mahasiswa bercadar.

Namun Informan 1 mengatakan bahwa saat hal tersebut terjadi Ia tidak tinggal diam, Ia menjelaskan bahwa hal tersebut bukan hal yang baik "Saya tegur dengan tegas dan keras kepada kawan saya maupun orang lain, saya menjelaskan kepada mereka tentang cadar dan kenapa mereka bercadar, dan setelah saya jelaskan semuanya hati mereka tersentuh dan akhirnya meminta maaf kepada si wanita bercadar itu."

Dari hasil penelitian di atas ada beberapa faktor yang menjadikan UTU bertindak pro terhadap mahasiswanya yang bercadar. Hal ini berbeda dengan beberapa kampus di Jawa yang bahkan mengeluarkan peraturan untuk tidak bercadar di kampus. Faktor-faktor tersebut antara lain adalah:

1) UTU terletak di Kabupaten Aceh Barat, suatu kabupaten di Provinsi Aceh dimana wilayah Aceh merupakan satu-satunya wilayah yang menetapkan Syariat Islam.

2) Mahasiswa UTU mayoritas beragamas Islam dan sebagian dari mereka ada yang pernah sekolah di pondok pesantren.

3) Di UTU tidak ada peraturan mengenai pelarangan bercadar. Mahasiswa hanya dituntut untuk berpakaian sopan dan rapi.

4) Adanya rasa menghargai antarsesama manusia. Mereka menghormati hak-hak seseorang dalam mengambil keputusan.

5) Sikap mahasiswa bercadar di UTU dinilai jauh dari stigma yang selama ini berkembang. Bercadar tidak ada kaitannya dengan radikalisme dan terorisme.

\section{KESIMPULAN}

Indonesia terdiri dari banyak pulau, banyak budaya, dan juga banyak bahasa. Dengan segala keberagamannya sudah seharusnya masyarakat Indonesia terbiasa dengan perbedaan. Menjadi aneh juga apabila masyarakat menjadikan perbedaan tersebut sebagai alasan terjadinya diskriminasi dan pengucilan terhadap yang berbeda. Karena pada dasarnya setiap manusia itu sama di mata tuhan. UNESCO menyatakan bahwa semua manusia di muka bumi ini tidak ada yang berbeda. Semua manusia 
sama yaitu sebagai homo sapiens.

Pernyataan dari UNESCO baiknya kita pahami lebih dalam dan kita renungkan. Bagaimana dengan sesama pemeluk agama Islam membeda-bedakan sesama pemeluk agamanya dikarenakan atribut keagamaan mereka berbeda. Perbedaan di antara sesama pemeluk agama Islam baiknya tidak harus dibesar-besarkan. Apalagi bila menimbulkan konflik antarsesama. Sebagai pemeluk agama Islam baiknya mereka menyadari dimana bahkan di dalam agama yang mereka anut terdapat beberapa mazhab yang boleh mereka ikuti.

Seperti halnya cadar yang mereka gunakan karena mengikuti salah satu mazhab dalam Islam dimana mazhab tersebut mewajibnya untuk bercadar bagi pengikut wanita. Hal ini yang kemudian menjadi stigma negatif dari beberapa kalangan. Karena kelompok bercadar cenderung tertutup dan minoritas. Stigma negatif tersebut yang melahirkan diskriminasi bagi orang-orang yang bercadar. Media juga menjadi salah satu penyebar kebencian mengenai cadar. Di media sering diperlihatkan orang bercadar terkait dengan aliran keras, radikal dan teroris.

Namun diskriminasi ini tidak terjadi di Universitas Teuku Umar (UTU). Hal ini dikarenakan bukan hanya karena UTU berada di Aceh yang menerapkan syari'at Islam, atau karena banyak mahasiswanya berasal dari pondok pesantren, namun juga karena sikap saling menghormati dan menghargai antarsesama manusia yang terjalin di universitas tersebut sehingga stigma positif terhadap cadar terbangun dengan sendirinya.

Saran peneliti kepada masyarakat Indonesia untuk menumbuhkan rasa menghargai dan menghormati perbedaan. Karena dengan begitu Indonesia bisa menjadi negara yang aman dan tenteram tanpa ada konflik dan diskriminasi yang disebabkan oleh perbedaan mereka. Juga kepada pemerintah dan pihak-pihak yang berwenang memberikan peraturan tertentu untuk tidak mengcoreng hak-hak wanita bercadar. Karena pada dasarnya mereka sama, ingin memperoleh hak dalam segala bidang terutama pendidikan. Apabila masih ada yang mengeluarkan larangan bercadar bagi mahasiswanya, hal ini dapat diartikan mereka masih belum bisa menjadi manusia yang saling menghargai dan menghormati.

\section{REFERENSI}

Ahmadi, Dadi dan H, Aliyah Nur'aini. 2005. Teori Penjulukan. Mediator, Vol VI (2): 297-306).

Ahmadi, Dadi. 2008. Interaksi Simbolik: Suatu Pengantar. Mediator, Vol IX (2): 301-316).

Ali, Denny Januar. 2014. Menjadi Indonesia Tanpa Diskriminasi data, Teori dan Solusi. Jakarta: Inspirasi.

Dermawan, Mohammad Kemal dan Oli'i, Mohammad Irvan. 2015. Sosiologi Peradilan 
Pidana. Jakarta: Yayasan Pustaka Obor Indonesia.

Fatmawati. 2015. Stigmatisasi dan Perilaku Diskriminatif pada Perempuan Bertato. Jurnal Equilibrium Pendidikan Sosiologi. Vol III (1):1-9.

Lindholm, Tore, Jr, W.Cole Durham dan Tahzib-Lie, Bahia G. 2010. Kebebasan Beragama atau Berkeyakinan: Seberapa Jauh (Terjemahan dari: Facilitating Freedom of Religion or Belief: A Deskbook). Yogyakarta:Kanisius.

Mustofa. 2016. Geliat Perempuan Melawan Stigmatisasi (Studi Upaya Transformasi Konflik Tokoh Ayu dalam Novel "Akulah Istri Teroris" Karya Abidah El Khalieqy). Skripsi. Program Studi Sosiologi Agama. Fakultas Ushuluddin dan Pemikiran Islam. UIN Sunan Kajijaga Yogyakarta.

Mustofa, Imam. 2012. Terorisme: Antara Aksi dan Reaksi (Gerakan Islam Radikal sebagai Respon terhadap Imperialisme Modern). RELIGIA, Vol XV (1):65-87.

Novri, Mutiara Sukma. 2016. Konstruksi Makna Cadar Oleh Wanita Bercadar Jamaah Pengajian Masjid Umar Bin Khattab Kelurahan Delima Kecamatan Tampan Pekanbaru. JOM FISIP, Vol III (1): 1-12.

Nugroho, Bagus Prihantoro. 2018. Tentang Polemik Larangan Pakai Cadar di Kampus. https:/ / news.detik.com/berita/d-3901590/tentang-polemik-larangan-pakaicadar-di-kampus/2. Diakses Tanggal 20 April 2018.

Rusmiyanti, Mei. 2017. Perilaku Komunikasi Mahasiswi S1 yang Bercadar di IAIN Purwokerto. Skripsi. Program Studi Komunikasi dan Penyiaran Islam. Jurusan Penyiaran Islam. Fakultas Dakwah. Institut Agama Islam Negeri (IAIN) Purwokerto.

Sutrisno, Mudji dan Putranto, Hendar. 2005. Teori-Teori Kebudayaan. Yogyakarta: Kanisius.

Tanra, Indra. 2015. Persepsi Masyarakat Tentang Perempuan Bercadar. Equilibrium Pendidikan Sosiologi. Vol III (1):116-125.

Voaiindonesia.com. 2018. UIN Yogya Larang Mahasiswi Pakai Burka. https:// www.voaindonesia.com/a/uin-yogya-larang-mahasiswi-pakaiburka/4285565.html. Diakses Tanggal 20 April 2018. 